\title{
The Revival of Mudharabah Contract: A Proposed Framework
}

\author{
Siti Nurzahira Che Tahrim ${ }^{1}$, Mohd Zulkifli Muhammad ${ }^{1}$, Mohd Syakir Mohd Rosdi ${ }^{2}$, Mohd Nor Hakimin Yusoff ${ }^{1}$, \\ Azizah Musa ${ }^{1} \&$ Noormariana Mohd Din ${ }^{1}$ \\ ${ }^{1}$ Universiti Malaysia Kelantan, Malaysia \\ ${ }^{2}$ Universiti Sains Malaysia, Malaysia \\ Correspondence: Siti Nurzahira Che Tahrim, Universiti Malaysia Kelantan, Malaysia.
}

Received: May 1, 2019

doi:10.5430/rwe.v10n2p70
Accepted: June 1, 2019

Online Published: July 8, 2019

URL: https://doi.org/10.5430/rwe.v10n2p70

\begin{abstract}
Mudharabah is a profit-sharing partnership agreement of a business venture to carry out economic activities. Despite its potential socioeconomic benefits to the parties involved and to the society, the application of mudharabah is limited to engineered Islamic finance products which transform the conventional financial products into Shari'ah-compliant ones. We argue that, in order to realise the mudharabah true potentials, among others, the mudharabah contract needs to be revived. The purpose of this study is to propose a framework in reviving the mudharabah contract between the sahibul mal (capital provider/investor) and the mudharib (entrepreneur). The research methods used in this study are library research and content analysis. As a result, agency theory is recognised to be very relevant to the mudharabah contract. To revive the mudharabah contract, tahaluf concept (Islamic treaty with compliance with Shari'ah) is identified as the most suitable concept to be adopted. This proposed framework serves as guidance in formulating the data collection strategy from different perspectives i.e. from sahibul mal, mudharib, Shari'ah advisors and academicians.
\end{abstract}

Keywords: Mudharabah, contract, Aqad, framework, revive

\section{Introduction}

The financial domain in entrepreneurship ecosystem is provided by private or government-linked institutions and banks that extend financial assistance to the entrepreneurs. The current embedded financial capitalism which focuses on wealth and consumption maximization creates imbalanced state and self-destructive ecosystem. In contrast, values in Islamic economy urge moderation in material quests and thoughtful when making private decisions on public good, in addition to pragmatism. There are also philanthropies whose intention is to help the poor (Siddiqi, 2008), or angel investors who would risk their own money and benefit some returns while helping others, through investing in entrepreneur's income generating activities. Unfortunately, there are some issues surrounding this situation, whereby not all poor who received the capital are interested in entrepreneurship (Aliber, Kirsten, Maharajh, Nhlapo-Hlope, \& Nkoane, 2006; Gyebi, Owusu \& Etroo 2013). In addition, some capital receivers are too poor that they want to only utilise those capital raised for consumption rather than business activities (Fairbourne, Gibson, \& Dyer, 2007; Goral \& Akgoz 2017). The microfinance institutions are also often charging very high rates (Chhay, 2011) which burdening the budding entrepreneurs.

On another notes, an Islamic profit-sharing; mudharabah, is a contract between investor and entrepreneur. In mudharabah, the profit accumulated resulting from business activities must be shared on the predetermined contractual ratio and only the investor bears all economic losses so long the entrepreneur is doing the business uprightly (Kwon, 2007; Garaeva \& Ahmetzyanov 2018). This is a very fair model as the entrepreneurs are not strained, yet place reasonable sense of responsibility to make profit and share it with the investor. The entrepreneur also cannot use the capital for consumption as the investor is following the business performance after the disbursement of capital. Mudharabah could be one of the best solutions which cover at least financial, support and human capital domains. Since mudharabah is thus far only contracted as part of financial engineered products and fairly known by the investors and entrepreneurs, it is timely that its true potential should be tapped through direct mudharabah contract implementation via improvements on pure Mudharabah contract which should solve the agency problem and enhance relationship between the (angel) investors and the entrepreneurs. 
The objective of this paper is to propose a framework in reviving the mudharabah contract between the sahibul mal (capital provider/investor) and the mudharib (entrepreneur) in a pure investor-entrepreneur relationship context. This framework will be used in conducting a library and field research in developing an improved Mudharabah contract template for future use.

\section{Research Methodology}

In order to achieve the objectives outlined above, we used qualitative method; library research and content analysis on mudharabah and related theory and approach to explain the relationship between investor and entrepreneurs involved. This study is conducted based on these assumptions:

a) The investors to have positive attitudes to offer Pure Mudharabah if fair, clear and flexible Mudharabah contracts are in place.

b) The entrepreneurs to have positive attitudes towards delivering responsibilities in Pure Mudharabah if fair, clear and flexible Mudharabah contracts are in place.

c) Pure Mudharabah is operationalisable when parties involved in the legally binding Mudharabah contracts have positive attitudes towards conforming to the fair, clear and flexible terms and conditions of the contract.

\section{Selected Theory and Concept}

\subsection{Agency Theory}

Jensen and Meckling (1976) introduced agency theory in an organisation whereby principal that is the owner, investor or shareholder of the company has to engage with the managers as their agent to manage and perform tasks for the business on their behalf. The agency costs arise when both the principal and agent have conflicting self interests. The principal's interest is for the agent to maximise wealth of the business venture, while the managers' interest is to maximise leisure on job, offer special dealing with their preferred clients, outright theft, take high risk activities and so on, which in turn will increase expenses and reduce profit of the corporation $(\mathrm{Ge}$, et.al 2018).

Based on this theory, the principal mentioned has very similar role as sahibul mal in mudharabah contract, who provides the capital into the business. On the other hand, the agent in the agency theory also has similarities with the mudharib in mudharabah. This is such because the mudharib has the responsibilities to manage the business as the basic requirements of sahibul mal which are to grow the capital and earn profit with business activities which are allowed by the Shariah.

As the profit will be shared between the sahibul mal and the mudharib, the agency cost can be reduced as both parties are aiming the same goal; to maximise the profit of the business venture. The agency problems however, arise when both parties have different limitations, whereby the sahibul mal needs to bear fully the business losses due to unfavourable economic condition, while the mudharib needs the trust from the sahibul mal that he/she can execute the business activities independently without any sahibul mal's intervention. To ensure that the mudharib is not taking actions and making decision with negligence, some penalty to bear the losses by the mudharib should be clearly written in the contract, understood and agreed. Likewise, the sahibul mal must also aware of his/her limitation of refraining from intervening in making business decisions and actions. For these similarities, Agency Theory is obvious to be very related to mudharabah contract. Among others, some studies that advocate with the relevancy of Agency Theory with mudharabah include those done by Abdul-Rahman, Abdul Latif, Muda, and Abdullah (2014), Samad, Gardner and Cook (2005) and Khalil, Rickwood and Murinde (2002).

\subsection{Tahaluf Concept}

Tahaluf Siyasi (political treaty) was discussed in length on how it is related to the benefits of society in general and benefits to political unity in particular (Mohd Syakir, 2015; Fiscal, 2018). In the discussions, six principles, four features and six conditoins are elaborated. They first principle is defending the truth; second, the principle of maintaining peace; third, the principle of compliance to agreement with Allah SWT; fourth, the principle of upholding an agreement; fifth, the principle of being firm with non-Muslims, and sixth, the principle of seeking mardhatillah (Allah's pleasure) as the ultimate goal.

As for the features of tahaluf siyasi, there are four features drawn. First, there is tenure of the agreement; second, the agreement is void if terms are violated; third, agreement is clearly documented and fourth, the agreement is sealed with Allah SWT as witness and source of strength. In terms of conditions of tahaluf siyasi, there are six conditions to satisfy. First, loyalty; second, sincerity; third, smart management; fourth, firm stance; fifth, ukhuwah (maintaining good relationship) and sixth, having confidence in the treaty. When comparing the mudharabah with tahaluf concepts, there are a lot similar situations in both of the concepts. While adoption of all of tahaluf concept is best, some possible 
concepts which mudharabah can adopt from tahaluf concept include the principle of fairness and most of the features. Smart management as a condition of tahaluf can be adopted in selecting mudharib to ensure conditions to profit in mudharabah are met. Figure 1 shows the comparisons and adoption of the two concepts.

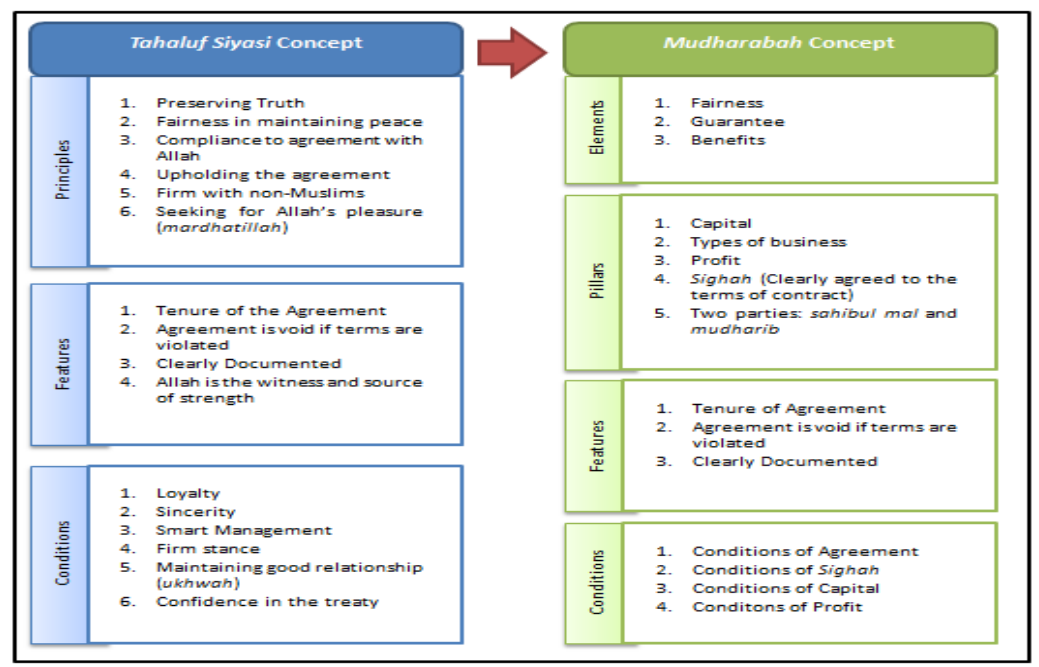

Figure 1

\section{Proposed Framework to Revive Pure Mudharabah Contract}

The revival of mudharabah contract is vital to increase the success of its implementation. Based on the discussions above, we therefore propose conceptual framework which combines the mudharabah concept with Agency Theory (Jensen \& Meckling, 1976) and Tahaluf Concept (Mohd Syakir, 2014). The following figure is the proposed framework.

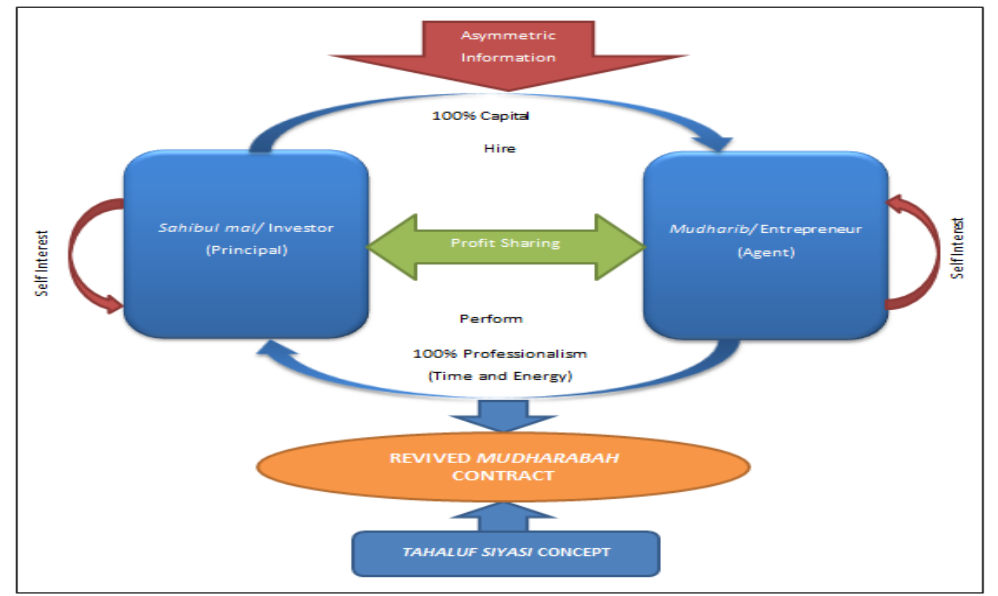

Figure 2

\section{Conclusion}

As part of the efforts to contribute to this transformation, the revival of the mudharabah contract is imperative as the current contract revolves around banking regulations. To revive the contract, agency theory and tahaluf concept are incorporated into the framework, to ensure all the important terms are included in the agreement. By incorporating agency theory to the framework, the similarity in the relationship may guide the mudharabah contract writing to include the measures to solve expected agency problems which would arise in the mudharabah implementation. 
The adoption of tahaluf concept such as the principle of fairness to maintain peace, features which include tenure of the agreement, voiding the agreement when the terms are violated and documenting the agreement clearly, as well as smart management condition of the tahaluf concept serve as a reference in mudharabah contract revival in considering the terms of the contract. The adoption of the tahaluf concept is hoped to preserve the spirit and realise the real substance of mudharabah. This proposed conceptual framework will be used as a guide when collecting data from interested parties in mudharabah such as investors, entreprenuers, Shariah advisors and academicians. The data collected from these potential informants will be analysed to formulate a revived mudharabah contract.

\section{References}

Abdul-Rahman, A., Abdul Latif, R., Muda, R., \& Abdullah, M. A. (2014, June). Failure and potential of profit-loss sharing contracts: A perspective of New Institutional, Economic (NIE) theory. Pacific-Basin Finance Journal, 136-151. https://doi.org/10.1016/j.pacfin.2014.01.004

Aliber, M., Kirsten, M., Maharajh, R., Nhlapo-Hlope, J., \& Nkoane, O. (2006). Overcoming underdevelopment in South Africa's second economy. Development Southern Africa, 23(1), 45-61. https://doi.org/10.1080/03768350600556356

Chhay, D. (2011). Women's economic empowerment through microfinance in Cambodia. Development in Practice, 21(8), 1122-1137. https://doi.org/10.1080/09614524.2011.606891

Fairbourne, J. S., Gibson, S. W., \& W. Gibb Dyer, J. (Eds.). (2007). Micro Franchising: Creating Wealth at the Bottom of the Pyramid. Micro Franchising Creating Wealth at the Bottom of the Pyramid. Massachusetts: Edward Elgar Publishing Limited.

Fiscal, R. R. (2018). Participation, Barriers and Preferences of Senior Citizens on Physical Activities. International Journal of Asian Social Science, 8(11), 1039-1047. https://doi.org/10.18488/journal.1.2018.811.1039.1047

Garaeva, A. K., \& Ahmetzyanov, I. G. (2018). Awareness of Historical Background as One of the Factors of Better Language Acquisition. International Journal of English Language and Literature Studies, 7(1), 15-21.

Ge, J., Wang, X., Wu, P., Huang, T., \& Jiang, H. (2018). Establishing Shipping Service Complex Standard Framework: Experience from Shanghai. International Journal of Management and Sustainability, 7(4), 215-224. https://doi.org/10.18488/journal.11.2018.74.215.224

Goral, R., \& Akgoz, E. (2017). Tourism Price Competition Index for National Destinations. Journal of Tourism Management Research, 4(1), 17-29. https://doi.org/10.18488/journal.31.2017.41.17.29

Gyebi, F., Owusu, M., \& Etroo, J. K. (2013). Foreign Direct Investment and Gross Domestic Product in Ghana. International Journal of Academic Research in Accounting, Finance and Management Services, 3(3), 256-65. https://doi.org/10.6007/IJARAFMS/v3-i3/153

Jensen, M. C., \& Meckling, W. H. (1976). Theory of the firm: Managerial behavior, agency costs and ownership structure. Journal of Financial Economics, 3, 305-360. https://doi.org/10.1016/0304-405X(76)90026-X

Khalil, A.-F. A. A., Rickwood, C., \& Murinde, V. (2002). Evidence of Agency-Contractual Problems in Mudharabah Financing Operations by Islamic Banks. In M. Iqbal \& D. T. Llewellyn (Eds.), Islamic Banking and Finance: New Perspectives on Profit-Sharing and Risk (pp. 57-94). Cheltenham, United Kingdom: Edward Elgar Publishing Limited.

Kwon, W. J. (2007). Islamic Principle and Takaful Insurance : Re-evaluation. Journal of Insurance Regulation, 53-82.

Mohd Syakir, M. R. (2014). Tahaluf Siyasi Dalam Ekonomi Politik Islam: Satu Kajian Teoretis. Pulau Pinang, Malaysia: Universiti Sains Malaysia.

Mohd Syakir, M. R. (2015). Tahaluf siyasi dalam ekonomi politik Islam. Ekonomika, 3(1), 56-82.

Samad, A., Gardner, N. D., \& Cook, B. J. (2005). Islamic banking and finance in theory and practice: The experience of Malaysia and Bahrain. The American Journal of Islamic Social Sciences, 22(2), 69-86.

Siddiqi, K. (2008). Potential of Islamic Microfinance in Pakistan. Loughborough University. 